\title{
Economic Development Perspective and City Leadership
}

\author{
James Vanderleeuw, ${ }^{1}$ Christopher Jarmon, ${ }^{2}$ Michael Pennington, ${ }^{3}$ \\ Thomas Sowers, ${ }^{1}$ and Terri Davis ${ }^{1}$ \\ ${ }^{1}$ Department of Political Science, Lamar University, 4400 MLK Boulevard, Beaumont, TX 77710, USA \\ ${ }^{2}$ Bush School of Government and Public Service, Texas A\&M University, 4220 TAMU, College Station, TX 77843, USA \\ ${ }^{3}$ Department of Public Administration, University of North Carolina at Pembroke, 1 University Road, Pembroke, NC 28372, USA
}

Correspondence should be addressed to James Vanderleeuw, vanderlejm@my.lamar.edu

Received 7 June 2011; Revised 30 August 2011; Accepted 5 September 2011

Academic Editor: Annette Hastings

Copyright ( 2011 James Vanderleeuw et al. This is an open access article distributed under the Creative Commons Attribution License, which permits unrestricted use, distribution, and reproduction in any medium, provided the original work is properly cited.

\begin{abstract}
The viability of traditional economic development strategies has long been questioned by urban policy scholars; yet traditional strategies remain the norm among city leaders. Traditional concerns emphasize economic and business considerations at the expense of nontraditional community considerations such as quality of life. In this paper, we examine the conditions under which city leaders give weight to nontraditional community concerns when making economic development decisions. Our analysis of the results of a survey conducted of more than 200 leaders in over 150 Texas cities indicates that although traditional economic development concerns remain dominant, certain conditions may exist that allow or compel city leaders to give increased weight to non-traditional community considerations. Conditions revealed by our study include the socioeconomic status of Texas cities and the relative differences in leadership positions and professionalism among city leaders. The paper concludes with a discussion of how our study contributes to the literature about economic development policy and points to avenues for future research on the conditions under which decision-making strategies are pursued by city leaders.
\end{abstract}

\section{Local Economic Development: Traditional and Nontraditional Thinking}

Economic growth is a primary responsibility for city leaders in the United States. Efforts to achieve economic growthwhether pursued because of the structural placement of cities in the US federal system [1], the interests of developers [2], the electoral benefits to city leaders $[3,4]$, or lack of state or federal financial assistance-are paramount to city leaders. Exploration into why city leaders pursue economic growth is much less informative to contemporary urban policy studies than analyzing the strategies leaders employ to reach the goal of economic growth. A study of the strategies used for achieving economic growth is particularly relevant in times of severe economic downturn when city budgets are stretched to capacity and traditional economic development strategies may not be sufficient to address a wide range of economic problems.

Economic development in the United States has traditionally involved a process by which local governments use their resources to stimulate private investment [5]. Numerous studies throughout the years have showcased the types of city activities that characterize economic development policy. To retain or attract business, local leaders have pursued strategies that include tax abatements, land clearance, the use of public money to provide infrastructure for private development, an emphasis on downtown business interests, and similar policies with a direct connection to job creation and city revenue (see e.g., [6-14]. In recent decades, scholars have challenged traditional economic development by pointing to efforts that have been made by some city leaders to address broader community concerns within the context of economic development (e.g., "linkage" fees assessed on developers to fund social projects such as lowerincome housing, along with other "Type II" policies that seek to more evenly distribute the benefits of development) [15, 16]. Such challenges have called attention to the potential economic benefits cities could gain by pursuing activities that were often considered as having little to do with economic growth, such as the arts [17] and nonprofits [18]. 
More recent studies have urged the benefits of expanding considerations of the cultural, entertainment, and lifestyle aspects of community life. Florida [19], for example, argues that successful economic development efforts can depend upon attracting and retaining a "creative class" (e.g., artists), a technologically based industry, and a culturally tolerant population (e.g., tolerant of gay rights). Employing a human capital model, Florida suggests that if leaders focus on attracting and retaining people, business will follow. While debate on this creative thesis continues, some scholars make broadly compatible arguments about the significance of cultural and entertainment opportunities for a city's population and its political and business leadership (see, e.g., $[20,21])$. In short, the economic growth aspects of what can be labeled nontraditional activities are recognized and promoted as an alternative to the traditional approach, at least among a cohort of scholars.

The extent to which the thinking of practitioners mirrors that of some scholars is an open question; however, it seems fair to say that most city economic development efforts have continued in the traditional vein [22, 23]. Despite continued pursuit of traditional economic strategies by most city leaders, a modern public appears more watchful of political leaders and less prone to accept the adverse consequences of decisions that threaten the broader quality of life than in the past. Lubell et al. note that "as growth pressures intensify, many citizens will begin to demand growth management in order to preserve community resources" ([24]: 650). Growth management demands may increasingly signal the need for city leaders to give greater weight to a broader mix of community considerations that yield different types of strategies_-some we can label traditional, others, nontraditional. The guiding question of our analysis is as follows: under what conditions are city leaders more likely to consider nontraditional community concerns when deciding on economic development strategies for their city?

\section{Economic Development Perspective, Leadership Position, and Level of Professionalism}

To answer our question, we focus on city leadership. City economic development policy is formulated, and decisions are made by a leadership cohort. City leadership, however, is not monolithic; rather, it represents different sectors (i.e., public, private, and nonprofit) as well as different institutions and constituencies that vary depending upon locality. Our analysis investigates the economic development perspectives of a particular set of leaders involved in city-level decision making about economic policy specifically those of mayors, managers, council presidents, and chamber of commerce and economic development corporation leaders. While this leadership set does not necessarily include the full spectrum of economic development participants in each city, and while the respective leaders identified in our set may not play the same roles in any given city, economic policy studies indicate these five institutional actors tend to play significant roles in city economic development (see e.g., [25], forthcoming,
[26], regarding economic development corporations; [27, 28], for city managers; [29] for mayors; [30] regarding local chambers; [31] for city councils). Furthermore, these five officeholders are representative of the types of institutional city leaders we find in Texas, the state from which our data are drawn (discussed below).

Having identified our leadership set, we then test for the influences city leadership position and level of professionalism have on the economic development perspectives of each of the five types of city leaders. By "economic development perspective," we refer to the attitudes city leaders hold about what is most important to their city's economic growth. The economic development perspective of a city's leadership is a crucial link between policy inputs (e.g., business interests, citizen demands, and policy proposals) and policy outputs (the types of strategies pursued). Regarding city leadership position, we theorize that city leaders separate along two important dimensions-sector and proximity to the mass citizenry. "Sector" involves the association that exists between public and private actors and the influences public/private association might have on the economic development perspective of city leaders. Our understanding of sector is further guided by an enduring theme in public administration-the concept of "public ethos" or ethic (see, e.g., [32-34]). Public ethos embodies a desire to serve the public and includes a balancing of what we normally think of as "public" and "private" interests. It is, in theory, a "calling" that motivates entry into public service or is instilled over time by public-sector employment. Private-sector business leaders, on the other hand, are presumed to be relatively lacking in public ethos and ostensibly place greater importance on economic and business concerns. Applying the concept of public ethos to the economic development perspective of city leaders, we hypothesize the following: by comparison to public-sector city leaders, private-sector business leaders will accord greater importance to traditional economic development concerns (Hypothesis 1).

The second dimension of city leadership position we examine is the proximity of city leaders to the mass citizenry. Our model for understanding the relationship between leaders and citizenry is guided by the "delegate" and "trustee" styles of representation. The delegate style of representation is most often assumed by publically elected leaders who are more proximate to the mass citizenry than are their appointed counterparts. Retaining an elected position can often depend upon the attention an elected leader gives to the immediate and specific concerns of their particular constituency which in turn informs his or her delegate style of representation. Appointed leaders, on the other hand, are less proximate to the mass citizenry and more insulated from the demands of the public, and, therefore, have greater flexibility to act as trustees of the public interest. Because of their respective proximities to the citizenry, elected leaders must give greater weight to the immediate dictates of the public while appointed leaders can rely more on their own training, experience, and judgment. Certain appointed leaders such as city managers, however, must act along a delegate/trustee continuum since they are appointed to 
their positions but nonetheless remain accountable to elected leaders.

The delegate and trustee concepts lead us to expect that the economic development perspective of elected leaders will reflect city socioeconomic conditions. Postmaterialist theory postulates that economic prosperity results in a shift in societal values away from a focus on "bread and butter" economic issues such as jobs, and toward quality of life issues, such as environmental protection. Some empirical evidence supports this theory (see e.g., [35-38]). Applying Postmaterialist theory, we expect elected leaders to be concerned with traditional economic development considerations when socioeconomic conditions are poor and more concerned with nontraditional considerations when city conditions are good. In contrast, we expect the perspective of appointed leaders to vary less in relation to city socioeconomic conditions. Accordingly, we hypothesize the following: by comparison to appointed city leaders, the economic development perspective of publicly elected leaders will be more reflective of city socioeconomic conditionsreflecting traditional concerns in lower socioeconomic status cities and nontraditional concerns in higher socioeconomic status cities (Hypothesis 2).

In addition to testing for city socioeconomic condition, we test for the level of professionalism among city leaders and the influence professionalism has on the economic development perspectives of city leaders. The level of professionalism includes both education and work experience. Education, particularly an advanced degree, instills conceptual "lenses" that structure perceptions about the world in which a city leader operates. This type of professionalization can cause city leaders to rely more on professional norms than on individual organizational needs [39-42]. Professionalism gained through on-the-job work experience is a socialization process by which city leaders become similarly inculcated with job "norms" that may produce a progrowth orientation [43].

We predict professionalism will heighten the emphasis both city leaders and private-sector business leaders place on traditional considerations of economic development. In both cases, higher education likely means enhanced emphasis on administration, business, and economics (via degrees in business and public administration), and on-thejob experience means reinforcement of job norms derived from job duties associated with city budgets, revenues, and the interests of commerce. Therefore, we hypothesize the following: as the level of education and job experience among private-sector and appointed city leaders increase, the greater the importance these leaders will accord traditional economic development concerns (Hypothesis 3). Regarding elected city leaders, we anticipate that their status as delegate style representatives will mitigate the influence of professionalism in that success as an elected leader necessitates a level of attentiveness to constituency interests regardless of the level of professionalism.

We investigate differences in economic development perspective across four areas-one that measures traditional economic development concerns and three that measure nontraditional concerns. The three nontraditional concerns tested for are quality of life, planning, and regional economic growth. These nontraditional concerns were chosen because each has a potential influence on economic growth. Should the human capital model posited by Florida [19] be correct, quality of life amenities can enhance economic growth by attracting business. Additionally, a city's comprehensive plan can encompass numerous goals such as public health, environmental protection, and city fiscal well-being that bear directly or indirectly on economic growth [44]. Finally, some studies particularly those supporting Postmaterialist theories in public administration indicate a higher propensity toward quality of life concerns among cities with greater economic prosperity [35-38]. Given the wide range of economic conditions that exist among cities, and given that cities in the same geographic region in the United States have tended not to pursue cooperative strategies to enhance the overall economic development of their region, a study of the influences that compel city leaders to pursue the nontraditional concerns of quality of life, planning, and regional economic growth contributes to our understanding of the variations in economic development perspectives among city leaders.

\section{Data and Method}

Our analysis is based on responses to mail-out surveys of city leaders in Texas during the fall of 2005 and spring of 2006. The surveyed positions were those of mayor, council president (or in some cases mayor pro-tem), city manager, chamber of commerce president, and economic development corporation (EDC) director. ${ }^{1}$ All surveys contained the same core set of questions and targeted cities with a population of at least 5,000 as determined by the 2000 census (cities in Texas can operate under a home rule charter when their population reaches this threshold). In all, 227 leaders from 159 cities responded (upon request, a list of cities can be provided). Thirty-five respondents were mayors (15.4\%), 48 were city managers $(21.1 \%), 65$ were council presidents (28.6\%), 49 were chamber presidents $(21.6 \%)$, and 30 were EDC directors (13.2\%). According to the 2000 census, 337 cities in Texas had a population of 5,000 or above. Three hundred and thirty-seven surveys were sent for each leadership position. Not every city had every leadership position (e.g., an EDC director), but, in lieu of a definitive list of cities with a population of 5,000 or above for each position, we found it expedient to send a survey to each city for each position. For this reason, a precise response rate for each position was difficult to determine. However, since cities have a mayor and a council, a calculation of the response rate for these offices was $10.4 \%$ for mayors and $19.3 \%$ for council members.

Our analysis employed a series of dependent variables derived from a list of economic development items respondents were asked to rank. The question presented was as follows: in order to determine how your city responds to new economic development project proposals and/or seeks to attract new development, please rank the following 13 considerations in order of importance with 1 being what is most important to your city and 13 being what is least important to your 
city. The items as they appeared on each survey were (1) conformity with your city's general plan, (2) contribution to your region's economy, (3) views of other nearby local governments, (4) creation of jobs for your city's residents, (5) generation of additional revenue for your city, (6) cost to your city of providing additional municipal services, (7) improvement in community aesthetics, (8) impact on the environment, (9) effect on traffic in your city, (10) support from your local chamber of commerce and local business, (11) impact on downtown redevelopment, (12) support from citizens or citizen groups in your city, and (13) support from other city leaders. (This question was inspired by Lewis' [45] study of administrators' attitudes toward economic development in California cities.) Because higher values are intuitively understood as more important, for our analyses the rank accorded each item is reversed (14-y) so that a higher value indicates a greater level of importance.

For our present study, we utilized 10 of the 13 items. The responses on these 10 items were aggregated into four categories-one category that measured traditional economic development and three that measured nontraditional concerns. ${ }^{2}$ The result was four indexes_-Traditional, Quality of Life, Regional Impact, and Planning — created by dividing the total score across all items in an index and dividing this by the number of items. This generated an index that provided the average rank given to items in a category. By taking the average rather than the sum, we were able to better compare the indexes because they were identically scaled.

Results for the survey items on jobs, revenue, cost of additional services, and downtown development reflected the job creation and fiscal concerns associated with traditional economic development (standardized for these four items, Mean $=8.67, \mathrm{SD}=1.38$, Range $=3.5-11.5$ ). Results for the survey items on community aesthetics, the environment, and traffic comprised our quality of life category (standardized for these three items, Mean $=5.79, \mathrm{SD}=1.76$, Range $=$ 2-11). The survey item regarding a city's general plan was our measure of the importance city leaders gave to planning (Mean $=7.84, \mathrm{SD}=3.20$, Range $=1-13)$. Results for the survey items on a region's economy and the views of nearby local governments were our measure of city leaders holding a regional perspective (standardized for these two items, Mean $=4.51, \mathrm{SD}=2.31$, Range $=1-13$ ).

Our analysis employed two key explanatory variablesleadership position and professionalism. We measured leadership position as mass proximity and sector. To address our theoretical concern with mass proximity, we categorized leadership positions into appointed (manager and EDC director coded 1, others 0 ) and elected (mayor and council president coded 1 , others 0 ). To address our theoretical concern with sector, we coded private (chamber presidents coded 1 , others 0 ). We employed two measures of city leader professionalism-level of education $(4.1 \%$ High School, 12.8\% Some College, 6.0\% Associates Degree, 41.3\% Bachelors Degree, 30.3\% Masters, and 5.5\% Ph.D.) and years in current position (Mean $=6.7, \mathrm{SD}=6.4$, Range $=$ 1-38). Because we expected elected city leaders to reflect social and economic conditions, we also examined for city socioeconomic status. To measure socioeconomic status we used two economic and one social indicator-percent unemployment (for surveyed cities Mean $=3.821, \mathrm{SD}=1.4$, Range $=1.1-9.7)$, median family income $($ Mean $=52,443$, $\mathrm{SD}=59,674$, Range $=18,208-481,125)$, and percent aged 25 and above with a Bachelor's degree (Mean $=8.4, \mathrm{SD}=$ 4.9 , Range $=1.1-27.0$ ) (all from 2000 census except percent unemployment, from January 2005).

Our analysis controlled for several potential city influences - population size, reform, and metro/rural status. Because leaders in a city with a large population may view their city as a regional economic "engine," we controlled for city size (for surveyed cities, Mean $=50,550, \mathrm{SD}=$ $135,421$, Range $=5,064-1,156,229)$. Because "reformed" cities are in theory more efficient with public money and have their historic genesis in a municipal reform movement promoted in part by business interests, traditional economic development concerns may be most pronounced in reformed cities. We, therefore, controlled for reform (cities coded 1 if they had a manager, 0 if not). Although cities in Texas are overwhelmingly reformed, $10 \%$ of surveyed city leaders (22) came from 16 nonreformed cities. Further, the emphasis given by city leadership to traditional concerns such as jobs and revenue can be influenced by geographic closeness to other communities that offer employment. Because rural communities tend to be geographically further from other communities, particularly large cities, rural community leaders may place particular importance on traditional economic development concerns. We, therefore, controlled for whether a city resides in a census-defined metropolitan area (coded 1 if metropolitan, 0 if rural). We received survey responses from 155 leaders from 109 metropolitan areas and 68 leaders from 50 rural communities.

\section{Descriptive Findings}

The following descriptive findings provide insight into the relationship between economic development perspective and leadership position. Variation in economic development concerns between city leaders exists, though it is modest and best understood within the context of the prevalence of traditional economic development considerations.

Table 1 reports the means for each of the thirteen survey items and the means for each of the five different leadership categories. By a simple examination of the means, we see that traditional economic concerns along with political process considerations are ranked highest in the survey. The trend to place the highest value on traditional economic concerns is consistent across all five categories with either creation of jobs or revenue ranking highest. The bottom categories are also remarkably consistent with views of nearby governments, downtown redevelopment, and the impact on the environment consistently ranking in the bottom three categories. There is little movement in item rank-ordering across leadership positions. Major exceptions can also be seen in Table 1. City councils are much less concerned with regional economies than other leaders with a 0.8 decrease in the mean compared to the baseline. The result is a drop of five places when rank ordering the categories. Leaders of Chambers of Commerce also diverge slightly from the mean. 
TABLe 1: Mean economic development item score for city leaders overall and by position.

\begin{tabular}{|c|c|c|c|c|c|c|c|}
\hline & & Overall & Mayor & Council & Manager & EDC & Chamber \\
\hline $\mathrm{T}^{\mathrm{a}}$ & Jobs & 10.7 & $\begin{array}{c}11.3 \\
(0.6)^{\mathrm{b}}\end{array}$ & $\begin{array}{c}10.3 \\
(-0.4)\end{array}$ & $\begin{array}{c}10.0 \\
(-0.7)\end{array}$ & $\begin{array}{l}11.5 \\
(0.8)\end{array}$ & $\begin{array}{l}11.0 \\
(0.3)\end{array}$ \\
\hline $\mathrm{T}$ & Revenue & 10.5 & $\begin{array}{l}11.2 \\
(0.7)\end{array}$ & $\begin{array}{c}10.4 \\
(-0.1)\end{array}$ & $\begin{array}{l}11.0 \\
(0.5)\end{array}$ & $\begin{array}{l}11.4 \\
(0.9)\end{array}$ & $\begin{array}{c}9.3 \\
(-1.2)\end{array}$ \\
\hline $\mathrm{T}$ & Service Cost & 7.9 & $\begin{array}{c}8.7 \\
(0.8)\end{array}$ & $\begin{array}{c}7.8 \\
(-0.1)\end{array}$ & $\begin{array}{c}8.9 \\
(1.0)\end{array}$ & $\begin{array}{c}7.2 \\
(-0.7)\end{array}$ & $\begin{array}{c}6.9 \\
(-1.0)\end{array}$ \\
\hline $\mathrm{P}$ & General Plan & 7.8 & $\begin{array}{c}8.1 \\
(0.3)\end{array}$ & $\begin{array}{c}8.6 \\
(0.8)\end{array}$ & $\begin{array}{c}7.9 \\
(0.1)\end{array}$ & $\begin{array}{c}7.2 \\
(-0.6)\end{array}$ & $\begin{array}{c}7.0 \\
(-0.8)\end{array}$ \\
\hline $\mathrm{R}$ & Region's Economy & 6.4 & $\begin{array}{c}6.5 \\
(0.1)\end{array}$ & $\begin{array}{c}5.6 \\
(-0.8)\end{array}$ & $\begin{array}{c}5.9 \\
(-0.5)\end{array}$ & $\begin{array}{c}6.9 \\
(0.5)\end{array}$ & $\begin{array}{c}7.8 \\
(1.4)\end{array}$ \\
\hline Q & Aesthetics & 6.4 & $\begin{array}{c}5.7 \\
(-0.7)\end{array}$ & $\begin{array}{c}6.5 \\
(0.1)\end{array}$ & $\begin{array}{c}6.0 \\
(-0.4)\end{array}$ & $\begin{array}{c}6.7 \\
(0.3)\end{array}$ & $\begin{array}{c}7.0 \\
(0.6)\end{array}$ \\
\hline Q & Traffic & 5.7 & $\begin{array}{c}5.0 \\
(0.7)\end{array}$ & $\begin{array}{c}6.3 \\
(0.6)\end{array}$ & $\begin{array}{c}5.6 \\
(-0.1)\end{array}$ & $\begin{array}{c}5.5 \\
(-0.2)\end{array}$ & $\begin{array}{c}5.6 \\
(-0.1)\end{array}$ \\
\hline $\mathrm{T}$ & Downtown & 5.6 & $\begin{array}{c}4.9 \\
(-0.7)\end{array}$ & $\begin{array}{c}6.1 \\
(0.5)\end{array}$ & $\begin{array}{c}5.8 \\
(0.2)\end{array}$ & $\begin{array}{c}4.6 \\
(-1.0)\end{array}$ & $\begin{array}{c}6.1 \\
(0.5)\end{array}$ \\
\hline Q & Environment & 5.3 & $\begin{array}{c}5.9 \\
(0.6)\end{array}$ & $\begin{array}{c}5.9 \\
(0.6)\end{array}$ & $\begin{array}{c}4.6 \\
(-0.7)\end{array}$ & $\begin{array}{c}4.7 \\
(-0.6)\end{array}$ & $\begin{array}{c}5.2 \\
(-0.1)\end{array}$ \\
\hline $\mathrm{R}$ & Nearby Gov'ts & 2.6 & $\begin{array}{c}2.3 \\
(-0.3)\end{array}$ & $\begin{array}{c}2.6 \\
(0.0)\end{array}$ & $\begin{array}{c}2.3 \\
(-0.3)\end{array}$ & $\begin{array}{c}2.1 \\
(-0.5)\end{array}$ & $\begin{array}{c}3.3 \\
(0.7)\end{array}$ \\
\hline & $\mathrm{N}$ & $209-213$ & $32-33$ & $59-61$ & $42-44$ & $28-30$ & $45-46$ \\
\hline
\end{tabular}

${ }^{\mathrm{a}} \mathrm{T}$ : Traditional, P: Planning, R: Regional, Q: Quality of Life.

${ }^{b}$ Values in parentheses are the percentage point difference in mean score from the base-line.

We see that leaders from the Chamber of Commerce value regional economics and citizens and interest groups concerns but are not very concerned about service costs.

We performed a descriptive analysis of city leader economic development perspective under varied city socioeconomic conditions and level of city leader professionalism with the expectation that results would provide valuable insight into these influences. We aggregated city leaders into type, appointed or elected, and sector, public or private, and economic development items into their four relevant categories - traditional, quality of life, regional, and planning. Because we anticipated that differences in economic development perspective would become most apparent when viewing extreme cases, we compared perspectives at the extreme ends of each city socioeconomic city indicator (using the 25th and 75th percentile) and each measure of city leader professionalism (using the 10th and 90th percentile). ${ }^{3}$

As expected, the relationship between economic development perspective and city leadership position was influenced by city socioeconomic status. Consistent with our hypothesis regarding the influence of city socioeconomic status on economic development perspective, the perspective of elected leaders appeared more responsive to city socioeconomic status than did the perspective of appointed leaders. In poorer and less educated communities, elected leaders were those who most emphasized traditional concerns, while in wealthier, more educated, and higher employment communities, elected leaders were those who most emphasized quality of life issues (Table 2(a)). Regardless of city income, elected leaders were those who most emphasized a regional perspective. Findings were less consistent regarding planning, with elected leaders placing most emphasis on planning in highly educated communities, and appointed leaders putting more importance on planning in poorer communities. The findings in Table 2, however, showed no statistically reliable association between economic development perspective and city leadership position when either years in office or level of education was taken into account (Table 2(b)).

When we compared the economic development perspective of public-sector with private-sector leaders (Table 3), we again saw that city socioeconomic status mattered. By comparison to private-sector leaders, public leaders most emphasized traditional concerns. This finding, however, applied only in less educated, poorer communities, and in communities with higher unemployment (Table 3(a)). Conversely, in poorer communities, private-sector leaders were those who most emphasized quality of life issues. Regardless of either city income or education, private more than public leaders held a regional perspective. There was a little difference regarding planning except in communities with higher unemployment, where private-sector leaders were those who placed the most emphasis on planning. The association between economic development perspective and leadership sector in some cases was reliably influenced by professionalism (Table $3(\mathrm{~b})$ ). With a greater number of years in office, private more than public-sector leaders emphasized a project's regional impact, though there was no difference in regional emphasis associated with educational 
TABLe 2: Mean economic development—appointed versus elected city leaders.

(a) Category Scores by City Socioeconomic Indicators

\begin{tabular}{|c|c|c|c|c|c|c|c|}
\hline & & \multicolumn{2}{|c|}{$\%$ Bachelors } & \multicolumn{2}{|c|}{ Median Family Income } & \multicolumn{2}{|c|}{ Unemployment } \\
\hline & & 25th $P$ & 75th $P$ & 25th $P$ & 75th $P$ & 25th $P$ & 75th $P$ \\
\hline & & $\leq 4.96$ & $\geq 11.05$ & $\leq \$ 33,919$ & $\geq \$ 54,253$ & $2.50 \%$ & $4.80 \%$ \\
\hline \multirow{2}{*}{ Traditional } & diff. $^{a}$ & -0.66 & 0.05 & -0.725 & 0.15 & 0.05 & 0.09 \\
\hline & $t$-score & $-1.77^{* *}$ & 0.1 & $-1.34^{*}$ & 0.33 & 0.11 & 0.23 \\
\hline \multirow{2}{*}{ Quality of Life } & diff. & 0.31 & -1.28 & 0.37 & -0.83 & -1.2 & -0.35 \\
\hline & $t$-score & 0.49 & $-2.28^{* *}$ & 0.52 & $-1.6^{*}$ & $-1.85^{* *}$ & -0.63 \\
\hline \multirow{2}{*}{ Regional Impact } & diff. & 0.25 & -0.25 & -1.25 & -1.23 & -0.04 & -0.71 \\
\hline & $t$-score & 0.34 & -0.35 & $-1.51^{*}$ & $-1.85^{* *}$ & -0.06 & -1.11 \\
\hline \multirow{2}{*}{ Planning } & diff. & 0 & -1.6 & 2.25 & -1.29 & -0.27 & -0.81 \\
\hline & $t$-score & 0 & $-1.65^{*}$ & $2^{* *}$ & -1.29 & -0.28 & -0.85 \\
\hline$N$ & & 33 & 39 & 28 & 38 & 40 & 42 \\
\hline
\end{tabular}

(b) Leader Attribute

\begin{tabular}{|c|c|c|c|c|c|}
\hline & & \multicolumn{2}{|c|}{ Years in Office } & \multicolumn{2}{|c|}{ Education Level } \\
\hline & & 10th $P$ & 90th $P$ & 10th $P$ & 90th $P$ \\
\hline & & $\leq 1$ & $\geq 15$ & $\leq$ Some Coll. & $\geq$ Masters \\
\hline \multirow{2}{*}{ Traditional } & diff. & -0.36 & 0.09 & 0.84 & -0.26 \\
\hline & $t$-score & -0.79 & 0.41 & 0.96 & -0.85 \\
\hline \multirow{2}{*}{ Quality of Life } & diff. & 0.49 & -0.1 & -1.13 & -0.41 \\
\hline & $t$-score & 0.8 & -0.14 & -1.17 & -0.97 \\
\hline \multirow{2}{*}{ Regional Impact } & diff. & 0.32 & 0.54 & -0.55 & 0.14 \\
\hline & $t$-score & 0.43 & 0.66 & -0.52 & 0.29 \\
\hline \multirow{2}{*}{ Planning } & diff. & -1.16 & -1.46 & -0.94 & 1.95 \\
\hline & $t$-score & -1.06 & -1.08 & -0.71 & $2.04^{* *}$ \\
\hline$N$ & & 33 & 24 & 24 & 85 \\
\hline
\end{tabular}

${ }^{\text {a }}$ Difference $=$ Public - Private.

${ }^{* * *} P<.01,{ }^{* *} P<.05,{ }^{*} P<.10$.

level. Furthermore, public leaders who most emphasized planning were those with fewer years in office combined with a higher level of education.

The findings in Table 3 did not support our hypothesis regarding private-sector leaders. Rather than private-sector leaders being most supportive of traditional concerns, when there was a reliable difference it was in public-sector leaders who were most supportive of traditional concerns. Overall, these findings offered mixed support for our hypotheses. To provide more definitive evidence, we turned to the results of our multivariate analysis.

\section{Multivariate Findings}

Table 4 reports results of multivariate equations that focused on the influence of city socioeconomic status on the economic development perspective of city leaders. ${ }^{4}$ The comparison group in these models was private-sector leaders.

We had hypothesized that by comparison to appointed city leaders, the economic development perspective of publicly elected leaders would be more reflective of city socioeconomic conditions - a hypothesis that reflected traditional concerns in lower socioeconomic status cities, and nontraditional concerns in higher socioeconomic status cities.
To gauge this relationship, we compared regression slope coefficients: the more responsive the leadership cohort to altered socioeconomic conditions, the more pronounced would be the slope. The standardized slope coefficients, Beta $(\beta)$, for the noninteractive leadership variables were essentially the same, .237 for appointed and .334 for elected leaders. However, the Beta for the elected leader interactive term (-.639) was substantially larger than the Beta for the appointed leader interactive term (.273).

Both appointed and elected leaders gave greater emphasis to traditional considerations than did private-sector leaders. As the socioeconomic status of a city increased, however, both appointed and elected leaders moved away from traditional considerations more than did private-sector leaders. Crucial to note, however, is that the responsiveness of elected leaders to altered city conditions (via giving diminished importance to traditional concerns as city socioeconomic conditions improved) was the most pronounced. While the findings in Table 4, Equation 1, supported our expectation regarding the influence of city economic conditions on the traditional economic development concerns of elected city leaders, they did not support our hypothesis regarding private-sector leaders. Both appointed and elected public leaders were reliably more supportive of traditional 
TABLE 3: Mean economic development-public versus private-sector city leaders.

(a) Category Scores by City Socioeconomic Indicators

\begin{tabular}{|c|c|c|c|c|c|c|c|}
\hline & & & ors & Median & Income & Une & ment \\
\hline & & 25th $P$ & 75th $P$ & 25th $P$ & 75th $P$ & 25th $P$ & 75th $P$ \\
\hline & & $\leq 4.96 \%$ & $\geq 11.05 \%$ & $\leq \$ 33,919$ & $\geq \$ 54,253$ & $\leq 2.5 \%$ & $\geq 4.8 \%$ \\
\hline Traditional & diff. $^{a}$ & 1.26 & -0.15 & 1.38 & -0.59 & -0.44 & 0.95 \\
\hline & $t$-score & $3.13^{*}$ & -0.32 & $2.59 * * *$ & -1.24 & -0.77 & $2.43^{* * *}$ \\
\hline Quality of Life & diff. & -0.89 & 0.33 & -1.08 & 0.67 & -0.44 & -0.06 \\
\hline & $t$-score & $-1.5^{* * *}$ & 0.57 & $-1.72 * *$ & 1.28 & -0.5 & -0.12 \\
\hline Regional Impact & diff. & -2.29 & -1.27 & -2.06 & -1.45 & 0.26 & -0.63 \\
\hline & $t$-score & $-3.02 *$ & $-1.59^{*}$ & $-2.61^{* * *}$ & $-1.74^{* *}$ & 0.27 & -0.99 \\
\hline Planning & diff. & 1.04 & 0.73 & 0.48 & 0.96 & -1.733 & 1.12 \\
\hline & $t$-score & 0.95 & 0.74 & 0.41 & 0.89 & $-1.41^{*}$ & 1.2 \\
\hline$N$ & & 44 & 52 & 38 & 51 & 44 & 58 \\
\hline
\end{tabular}

(b) Leader Attributes

\begin{tabular}{|c|c|c|c|c|c|}
\hline & & & & & \\
\hline & & 10th $P$ & 90th $P$ & 10th $P$ & 90th $P$ \\
\hline & & $\leq 1$ & $\geq 15$ & $\leq$ Some Coll. & $\geq$ Masters \\
\hline Traditional & diff. & 1.06 & 0.58 & 0.45 & -0.02 \\
\hline & $t$-score & $1.87^{* *}$ & $2.4^{* * *}$ & 0.74 & -0.06 \\
\hline Quality of Life & diff. & -0.26 & 0.60 & -0.22 & 0.22 \\
\hline & $t$-score & -0.36 & 0.79 & -0.34 & 0.43 \\
\hline Regional Impact & diff. & -0.86 & -2.39 & -2.74 & -2.74 \\
\hline & $t$-score & -0.96 & $-2.88^{* * *}$ & $-2.79 * * *$ & $-4.19^{* * *}$ \\
\hline Planning & diff. & 2.2 & 1.38 & 0.46 & 1.95 \\
\hline & $t$-score & $1.62^{*}$ & 0.99 & 0.45 & $2.04^{* *}$ \\
\hline$N$ & & 39 & 34 & 34 & 85 \\
\hline
\end{tabular}

${ }^{\mathrm{a}}$ Difference $=$ Public - Private.

${ }^{* * *} P<.01,{ }^{* *} P<.05,{ }^{*} P<.10$.

economic development considerations than were privatesector leaders.

The only nonsocioeconomic influence to have a statistically reliable relationship with traditional considerations was metropolitan status. Leaders in metropolitan area cities accorded greater importance to traditional economic development concerns than did leaders of rural communities. If appointed and elected leaders were less concerned with traditional considerations by comparison to private-sector leaders, what were they more concerned with? By comparison to private-sector leaders, both elected and appointed leaders emphasized planning, but deemphasized regional concerns (Table 4, Equations 3 and 4).

Table 5 reports the results of multivariate equations that focused on the influence of professionalism. ${ }^{5}$ The comparison group in these models was elected leaders.

We had anticipated that as the level of education and job experience among private-sector and appointed city leaders increased, the greater the importance these leaders would accord traditional economic development concerns. The findings in Table 5 indicated no relationship between economic development perspective and level of professionalism. The only reliable relationships were when the level of professionalism was accounted for private-sector leaders who were less concerned with both traditional economic development considerations and planning compared with public-sector leaders. Again, we had expected private-sector leaders to be most concerned with traditional considerations. This expectation was not borne out by the findings.

\section{Discussion}

Our research was guided by the following question: under what conditions are city leaders more likely to consider nontraditional community concerns when deciding on economic development strategies for their city? To address this question, we focused on differences between city leadership positions by employing results of a survey of five types of city leaders across Texas. Overall, our findings were consistent with the empirical findings of other scholars (e.g., [22]) that indicate that most city economic development efforts have continued in the traditional vein.

Our analysis indicates that traditional economic development concerns including priority given to downtown development, revenue, and jobs tend to comprise the dominant economic development perspective of city leaders in Texas. There is reliable variation, however, in economic development perceptive that is associated with leadership 
TABLE 4: Economic development perspective and city socioeconomic status.

\begin{tabular}{|c|c|c|c|c|c|c|c|c|}
\hline & & & \multicolumn{6}{|c|}{ Nontraditional } \\
\hline & \multicolumn{2}{|c|}{ Equation 1} & \multicolumn{2}{|c|}{ Equation 2} & \multicolumn{2}{|c|}{ Equation 3} & \multicolumn{2}{|c|}{ Equation 4} \\
\hline & Traditional & $(\beta)$ & Quality of life & $(\beta)$ & Regional & $(\beta)$ & Planning & $(\beta)$ \\
\hline Appointed X SES & $\begin{array}{c}-2.95 e-6^{* *} \\
(1.23 e-6)\end{array}$ & -.273 & $\begin{array}{c}9.09 e-7 \\
(1.50 e-6)\end{array}$ & .070 & $\begin{array}{l}-1.51 e-6 \\
(2.04 e-6)\end{array}$ & -.089 & $\begin{array}{l}-3.88 e-6 \\
(2.77 e-6)\end{array}$ & -.163 \\
\hline Elected X SES & $\begin{array}{c}-2.73 e-6^{* * *} \\
(1.00 e-6)\end{array}$ & -.639 & $\begin{array}{c}9.96 e-7 \\
(1.26 e-6)\end{array}$ & .173 & $\begin{array}{l}-2.69 e-7 \\
(1.75 e-6)\end{array}$ & -.037 & $\begin{array}{l}-3.51 e-6 \\
(2.32 e-6)\end{array}$ & -.352 \\
\hline Appointed & $\begin{array}{c}0.96^{* * *} \\
(.32)\end{array}$ & .327 & $\begin{array}{l}-0.54 \\
(0.40)\end{array}$ & -.145 & $\begin{array}{c}-1.15^{* *} \\
(0.55)\end{array}$ & -.237 & $\begin{array}{l}1.33^{*} \\
(0.73)\end{array}$ & .196 \\
\hline Elected & $\begin{array}{c}0.93^{* * *} \\
(.30)\end{array}$ & .334 & $\begin{array}{l}-0.22 \\
(0.38)\end{array}$ & -.064 & $\begin{array}{c}-1.33^{* *} \\
(0.52)\end{array}$ & -.285 & $\begin{array}{c}1.89 * * * \\
(0.69)\end{array}$ & .292 \\
\hline SES & $\begin{array}{l}2.19 e-6^{*} \\
(1.27 e-6)\end{array}$ & .537 & $\begin{array}{c}3.41 e-7 \\
(1.58 e-6)\end{array}$ & .066 & $\begin{array}{c}5.08 e-7 \\
(2.20 e-6)\end{array}$ & .074 & $\begin{array}{l}4.89 e-6^{*} \\
(2.92 e-6)\end{array}$ & .514 \\
\hline Median Family Income & $\begin{array}{l}1.49 e-6^{*} \\
(2.28 e-6)\end{array}$ & .007 & $\begin{array}{c}1.26 e-6 \\
(2.82 e-6)\end{array}$ & .045 & $\begin{array}{r}-5.20 e-6 \\
(4.31 e-6)\end{array}$ & -.123 & $\begin{array}{c}8.31 e-6 \\
(5.20 e-6)\end{array}$ & .015 \\
\hline$\%$ College & $\begin{array}{l}-0.05 \\
(0.04)\end{array}$ & -.180 & $\begin{array}{c}0.03 \\
(0.05)\end{array}$ & .092 & $\begin{array}{l}-0.05 \\
(0.06)\end{array}$ & -.106 & $\begin{array}{c}0.09 \\
(0.09)\end{array}$ & .145 \\
\hline \%Unemployment (Inv.) & $\begin{array}{l}-0.27 \\
(1.01)\end{array}$ & -.026 & $\begin{array}{c}0.40 \\
(1.27)\end{array}$ & .030 & $\begin{array}{c}1.86 \\
(1.72)\end{array}$ & .106 & $\begin{array}{l}-1.10 \\
(2.33)\end{array}$ & -.044 \\
\hline Metro & $\begin{array}{c}0.44^{* *} \\
(0.22)\end{array}$ & .150 & $\begin{array}{l}-0.02 \\
(0.28)\end{array}$ & -.005 & $\begin{array}{c}0.03 \\
(0.39)\end{array}$ & .005 & $\begin{array}{l}-0.39 \\
(0.52)\end{array}$ & -.055 \\
\hline Council-Manager & $\begin{array}{l}-0.01 \\
(0.36)\end{array}$ & -.001 & $\begin{array}{c}0.16 \\
(0.43)\end{array}$ & .027 & $\begin{array}{l}-0.15 \\
(0.59)\end{array}$ & -.020 & $\begin{array}{c}0.08 \\
(0.80)\end{array}$ & .007 \\
\hline Population & $\begin{array}{l}-1.13 \mathrm{e}-6 \\
(8.02 \mathrm{e}-7)\end{array}$ & -.099 & $\begin{array}{l}-6.28 \mathrm{e}-8 \\
(1.01 \mathrm{e}-6)\end{array}$ & -.004 & $\begin{array}{c}3.97 e-7 \\
(1.37 e-6)\end{array}$ & .021 & $\begin{array}{c}2.63 e-6 \\
(1.86 e-6)\end{array}$ & .094 \\
\hline Constant & $\begin{array}{c}8.19^{* * *} \\
(0.53)\end{array}$ & & $\begin{array}{c}5.29^{* * *} \\
(0.65)\end{array}$ & & $\begin{array}{c}5.72^{* * *} \\
(0.89)\end{array}$ & & $\begin{array}{c}5.71^{* * *} \\
(1.19)\end{array}$ & \\
\hline$N$ & 207 & & 208 & & 206 & & 211 & \\
\hline Adj. $R^{2}$ & .079 & & .093 & & .086 & & .128 & \\
\hline Prob $>$ F & .004 & & .093 & & .086 & & .079 & \\
\hline
\end{tabular}

$* * * P<.01, * * P<.05, * P<.10$; Standard Errors in Parentheses.

Appointed = Manager + EDC; Elected = Mayor + Council; SES = Median Family Income + \%College + \%Unemployment $($ Inv $)$.

position and city socioeconomic status. As we expected, our findings show that the economic development perspective of city leaders can reliably vary depending upon the particular leadership position. Also as expected, our findings show that the socioeconomic conditions of a city can influence the economic development outlook of city leaders, and that the level of influence is most pronounced for elected city officials. Unexpectedly, our findings reveal that private-sector leaders are not more oriented toward traditional economic development considerations than are public-sector city leaders. Also unexpectedly, our findings indicate no reliable relationship between economic development perspective and the level of professionalism among city leaders.

Our survey of city leaders ran from late 2005 through early 2006, and came to an end two years before the present Great Recession, an economic downturn that some observers claim to be the worst since the Great Depression of the 1930s. The economy appeared relatively healthy during the time of our survey, both nationally and in Texas. The unemployment rate in Texas was $5.9 \%$ and had remained virtually unchanged during the previous twelve months [46]. Texas initially proved to be somewhat insulated from economic downturn due to demand for oil and gas and its petrochemical economic base. However, several years after the onset of the Recession, the United States continues in its grip, and adverse economic conditions have hit the state of Texas. By August 2011, unemployment in the state had reached $8.4 \%$ [47]. While lower than the national average of $9.1 \%$ [48], the present rate represents an increase over the June level of $8.2 \%$ and is the highest level of unemployment in Texas since 1987 [49].

To return to an earlier point, a study of the strategies used for achieving economic growth is particularly relevant in times of severe economic downturn when city budgets are stretched and traditional economic development policies may be insufficient to address economic challenges. It is important to, therefore, speculate about what the economic development perspectives of city leaders would be if leaders were surveyed today. While we do not have systematic data regarding economic development perspectives in the present 
TABLE 5: Economic development perspective and city leader professionalism.

\begin{tabular}{|c|c|c|c|c|c|c|c|c|}
\hline & & & \multicolumn{6}{|c|}{ Nontraditional } \\
\hline & \multicolumn{2}{|c|}{ Equation 1} & \multicolumn{2}{|c|}{ Equation 2} & \multicolumn{2}{|c|}{ Equation 3} & \multicolumn{2}{|c|}{ Equation 4} \\
\hline & Traditional & $(\beta)$ & Quality of Life & $(\beta)$ & Regional & $(\beta)$ & Planning & $(\beta)$ \\
\hline Private X & 0.06 & .248 & -0.02 & -.055 & 0.04 & .117 & -0.04 & -.067 \\
\hline Professionalism & $(0.04)$ & & $(0.05)$ & & $(0.06)$ & & $(0.08)$ & \\
\hline Appointed X & 0.03 & .140 & 0.00 & .011 & -0.05 & -.115 & 0.02 & .038 \\
\hline Professionalism & $(0.04)$ & & $(0.05)$ & & $(0.07)$ & & $(0.09)$ & \\
\hline \multirow{2}{*}{ Private } & $-1.05^{* *}$ & -.316 & 0.10 & .024 & 0.88 & .157 & $-1.11^{* *}$ & -.145 \\
\hline & $(0.48)$ & & $(0.62)$ & & $(0.80)$ & & $(1.13)$ & \\
\hline \multirow[t]{2}{*}{ Appointed } & -0.19 & -.067 & -0.39 & -.102 & 0.43 & .086 & -1.11 & -.160 \\
\hline & $(0.47)$ & & $(0.62)$ & & $(0.78)$ & & $(1.10)$ & \\
\hline \multirow[t]{2}{*}{ Professionalism } & -0.19 & -.890 & 0.50 & 1.899 & -0.23 & -.672 & -0.77 & -1.591 \\
\hline & $(0.28)$ & & $(0.35)$ & & $(0.45)$ & & $(0.63)$ & \\
\hline \multirow[t]{2}{*}{ Years in Office } & 0.13 & -.632 & -0.47 & -1.754 & 0.29 & .816 & 0.82 & 1.684 \\
\hline & $(0.28)$ & & $(0.34)$ & & $(0.44)$ & & $(0.63)$ & \\
\hline \multirow[t]{2}{*}{ Less than Bachelors } & -0.19 & -.056 & 1.19 & .280 & -0.06 & -.011 & -2.27 & -.290 \\
\hline & $(0.63)$ & & $(0.78)$ & & $(1.01)$ & & $(1.42)$ & \\
\hline \multirow[t]{2}{*}{ Greater than Bachelors } & 0.34 & .116 & -0.24 & -.065 & 0.61 & .125 & 0.70 & .105 \\
\hline & $(0.40)$ & & $(0.50)$ & & $(0.65)$ & & $(0.90)$ & \\
\hline \multirow[t]{2}{*}{ Metro } & 0.22 & .072 & 0.41 & .108 & -0.01 & -.003 & 0.34 & .048 \\
\hline & $(0.23)$ & & $(0.29)$ & & $(0.37)$ & & $(0.52)$ & \\
\hline \multirow[t]{2}{*}{ Council-Manager } & -0.15 & -.031 & -0.01 & -.002 & 0.49 & .064 & 0.17 & .016 \\
\hline & $(0.35)$ & & $(0.44)$ & & $(0.58)$ & & $(0.80)$ & \\
\hline \multirow[t]{2}{*}{ Population } & $-1.02 e-6$ & -.091 & $-6.09 e-7$ & -.043 & $-5.64 e-7$ & -0.30 & $2.75 e-6$ & .105 \\
\hline & $(8.71 e-6)$ & & $(1.11 e-6)$ & & $(1.44 e-6)$ & & $(2.02 e-6)$ & \\
\hline \multirow[t]{2}{*}{ Constant } & $37.77^{* * *}$ & & $3.37^{* * *}$ & & $4.18^{* * *}$ & & $10.87^{* * *}$ & \\
\hline & $(2.32)$ & & $(1.50)$ & & $(1.94)$ & & $(2.73)$ & \\
\hline$N$ & 191 & & 193 & & 191 & & 195 & \\
\hline Adj. $R^{2}$ & .025 & & .001 & & .049 & & .014 & \\
\hline Prob > F & .155 & & .432 & & .042 & & .252 & \\
\hline
\end{tabular}

*** $P<.01,{ }^{* *} P<.05,{ }^{*} P<.10$; Standard Errors in Parentheses.

Private $=$ Chamber; Appointed $=$ Manager + EDC; Professionalism $=$ no. Years in Office + Level of Education .

economic situation, our findings may provide insight into the economic development outlook of city leaders in the context of the Great Recession given that they point to the significant influence city socioeconomic status has on the economic development outlook of city leaders. Adverse economic conditions heighten the focus of public-sector city leaders on traditional economic development elements. Public leaders give significantly greater weight to traditional considerations such as downtown development, city revenue, and job creation in communities with lower income, higher unemployment, and lower levels of education than do leaders of communities that are economically better off. Our findings also reveal that elected city leaders are particularly responsive to city socioeconomic conditions as compared to appointed leaders.

Scholars over time have challenged the traditional approach to local economic development in the United States, and many have called for increased attention to quality of life issues. Our findings suggest, however, that in better economic times city leaders deemphasize traditional considerations and in tougher economic times they emphasize traditional concerns. Applying these findings to our current recession climate, we posit that a shift away from relative economic health to an economy of austerity produces a correlated shift in the economic development perspectives of city leaders. Specifically, our findings suggest that uncertainty caused by downward shifts in national and local economies results in a "retreat" by city leaders from nontraditional ways of thinking about economic development to traditional thinking.

Economic uncertainty about the future, caused by high unemployment and lack of reliable resource streams, encourages perspectives (at least in the short term) that embrace well-known practices. Adopting a traditional model that emphasizes economic and business considerations at the expense of nontraditional quality of life issues guards against any accusation that "risky," nonproductive strategies might be employed. Additionally, elected leaders such as mayors and city council members can claim to be acting in the best economic interests of constituents (to borrow from a 
point made by Feiock et al. [4]). Even appointed officeholders such as city managers, however, are not immune from community and local interest-group concern (see e.g., $[50,51]$. A city manager's job can depend upon a satisfied elected leadership whose satisfaction can well depend on public mood.

A potential stumbling block to our theory of retreat arises when we consider that the traditional approach to local economic development in the United States has involved local governments using their resources to stimulate private investment (relying on Krumholz's, [5], definition). During a period of pronounced economic retrenchment-with fewer federal grants and little-if-any in the way of state resources, as well as a decided unwillingness of citizens to pay higher taxes-how can cities come up with the financial resources needed to promote, or subsidize, economic development projects in the hope of creating jobs or increasing revenue? If uncertainty leads to a retreat toward what is tried-andtrue, and if the tried-and-true depends on resources that are unavailable, the consequences may be less than optimal. One conceivable consequence is inaction. As city leaders retreat toward traditional economic development measures that focus attention on efforts that cannot be pursued due to lack of resources, they close off other avenues of consideration, thereby creating a climate of inaction.

For elected city leaders, inaction may not be the worst consequence. If economic conditions improve within some reasonable timeframe, the crisis passes and life goes on. In the meantime, rhetoric about what should be done and perhaps finger-pointing at other levels of government may suffice. Inaction, however, may be less viable both politically and in terms of ramifications for the lives of citizens the longer that economic recession continues. To borrow liberally from Lubell et al. [24], we might know that retreat has failed when normally low local voter turnout increases sharply and reflects citizen dissatisfaction via the defeat of local incumbents.

We believe our findings, based on city leaders in Texas, have a broad application for cities in other states. The extent to which state government is involved with local affairs can vary. Texas state government has a long tradition of staying out of local affairs and of leaving local growth and land use policy up to local government $[25,28,52]$. In the context of economic recession and austerity, diminished state (along with federal) resources require local units to increasingly provide for themselves. Our present national economic setting, therefore, may in some measure force a replication in many states of what has traditionally been the case in Texas-a laissez-faire state orientation toward local government. In the absence of external resources, and left to their own devices, city leaders will turn to traditional, "bread and butter," economic development considerations.

The influence of city socioeconomic status aside, our study reveals reliable differences in economic development perspectives held by different types of city leaders. First, our findings point to the importance of institutional expectations. Elected leaders such as mayors and council members are expected to be responsive to the public (or in Svara's [53] terms, to hold a "constituency orientation"). The outlook of these officeholders varies depending upon the socioeconomic conditions of their community. To a lesser, though still reliable, extent, the economic development perspective of appointed public leaders, managers and EDC directors, also varies with city socioeconomic conditions. As professional administrators, city managers are expected to be somewhat above the political fray. However, city managers are not immune from the possibility of replacement by elected leaders when under pressure from constituents to alleviate adverse economic or social conditions. City managers can and do get involved in policy formulation, and it seems fair to say that city managers are expected to help promote policy that keeps elected leaders in power. Because they are appointed by a governing board whose members are in turn appointed by the local council, economic development directors in Texas similarly are not divorced from the local political, economic, and social setting (see End Note ${ }^{1}$ ).

Given the nature of their constituency, local chamber of commerce presidents are expected to articulate the interests of business. Contrary to our prediction, though, chamber presidents are not more oriented toward traditional economic development concerns than are public-sector leaders. They do, however, hold a more regional view compared to other leaders. (see Table 4, Equation 3). We speculate that in terms of institutional expectations, local chamber presidents are expected to be oriented toward regional growth in order to advance business interests. Our speculation is premised on the idea that business vitality is enhanced through expanding the local market (i.e., outward from the city to the region). Our findings may, therefore, be compatible with the idea that chamber presidents are expected to hold a pronounced regional outlook.

Finally, we find it interesting that our analysis revealed no reliable association between economic development perspective and the level of professionalism among city leaders. We cannot conclude from this, however, that professionalism per se has no impact. Additional or alternate measures may be necessary to better "capture" the influence of professionalism. If we assume, for instance, that prior experience matters (as we did), then an additional measure might be the total number of years in public (or private) service and not solely the number of years in the present position. Furthermore, if we assume that the nature of the prior experience matters, then the number of years spent in prior executive positions as opposed to legislative or board positions might also contribute to capturing the influence of professionalism. Generally, more research is needed in this area. What our study does reveal is that neither the number of years in the present position nor the city leaders' level of education is associated with economic development outlook.

\section{Conclusion}

We conclude with some commentary on our analysis and thoughts for future research. Case study research provides an abundance of valuable information but leaves open questions about how the behavior under investigation "works" in the aggregate. A significant contribution of our present research to studies in urban policy is that it provides a systematic 
analysis of economic development perspectives across a variety of city leaders and across numerous cities. Our analysis can also be built upon. The majority of cities in Texas are reformed in that they employ city managers with part-time mayors and small and part-time city councils. An analysis of nonreformed, strong-mayor systems might shed light on the significance of the mayoral perspective on economic development, and an analysis of cities with large, full-time councils may provide enhanced insight into the influence of local legislative bodies.

Future research might also expand upon the mix of city leaders employed for analysis. The leadership cohort we examined was derived to a large extent from reformed cities. As noted earlier, we make no claim that the leadership cohort we identified is applicable to every city. And, significant economic development participants such as nonprofits, educational institutions, community groups, and relevant private-sector firms might also be identified. While our study employed several types of nontraditional economic development concerns, it could also be beneficial to expand the scope of nontraditional considerations to explicitly include items that pertain to cultural, entertainment, and recreational opportunities. Finally, our analysis employed several conditions that potentially influence economic development perspective-differences in leadership position, city socioeconomic status, and city leader professionalism. Future research expanding upon our findings might explore additional conditions and factors that affect economic development perspective such as sources of available information, association members, and the frequency and types of meetings attended.

\section{Endnotes}

1. Many cities in Texas utilize an economic development corporation (EDC). In 1979, the Texas state legislature gave cities the authority to establish city-level EDCs. Since that time, the use of EDCs has increased steadily. According to a recent count, there are over 600 EDCs in Texas [54]. The state legislature has empowered EDCs to pursue a range of local economic development activities. These include job training, infrastructure projects, seed money for start-up businesses, and improvements in amenities such as parks and recreational facilities. EDCs are primarily funded by a local sales tax. Local sales taxes in Texas cannot exceed $2.0 \%$, of which $0.5 \%$ can fund an EDC.

2. Our analysis excludes three survey items - support from other city leaders (ranked 4th among the 13 items with a mean of 8.5), support from citizen groups (ranked 6th with a mean of 7.5), and support from local business (ranked 9th with a mean of 6.4). While these items are relevant for other research, they do not fit the focus of our present study because they deal with career and political motivations of leaders. While these items could be transformed into a fifth index measuring political and career aspirations of political leaders, we selected to omit this index because political concerns are likely to be driven by factors outside our present theoretical framework. It is, for example, unlikely that a mayor is going to stop caring about the opinions and views of citizens when the economic situation in a city improves. Essentially, our theory provides no hypotheses for this dependent variable, and from the perspective of our set of independent variables we believe a political/career index would be unrelated.

3. To identify extreme cases for the socioeconomic indicators, we initially used the 10th and 90th percentile. There proved to be few cases for analysis at these levels.

4. Our multivariate analyses displayed in Table 4 test for the separate as well as the combined influences of city socioeconomic status measures. The composite variable, SES, is as follows: Family Income $\mathrm{X}$ \%College $\mathrm{X}$ \%Unemployment. Each variable is calibrated in the same direction, \%Unemployment was inverted as follows: \%Unemployment/1. As a result, higher values for each city socioeconomic status indicator-Median Family Income, \%College and \%Unemploymentindicate higher socioeconomic status.

5. Our multivariate analyses displayed in Table 5 test for the separate as well as the combined influence of the city leader professionalism measures. The composite variable, Professionalism, is as follows: Years in Position $\mathrm{X}$ Level of Education.

\section{References}

[1] P. Peterson, City Limits, University of Chicago Press, Chicago, Ill, USA, 1981.

[2] H. Molotch, "The city as a growth machine: toward a political economy of place," American Journal of Sociology, vol. 82, no. 2, pp. 309-332, 1976.

[3] R. Feiock, H.-J. Park, A. Steinacker, and J.-H. Kim, "Institutional collective action and economic development joint ventures," in Proceedings of the Bi-Annual Meeting of the Public Management Research Association, Los Angeles, Calif, USA, October 2005.

[4] R. C. Feiock and J. H. Kim, "Form of government, administrative organization, and local economic development policy," Journal of Public Administration Research and Theory, vol. 11, no. 1, pp. 29-49, 2001.

[5] N. Krumholz, "Equitable approaches to local economic development," Policy Studies Journal, vol. 27, no. 1, pp. 83-95, 1999.

[6] B. Ross and M. Levine, Urban Politics: Power in Metropolitan America, Peackock, Itasca, Ill, USA, 2001.

[7] C. Leo, M. Beavis, A. Carver, and B. Turner, "Is Urban Sprawl back on the political agenda? Local growth control, regional growth management, and politics," Urban Affairs Review, vol. 34, no. 2, pp. 179-212, 1998.

[8] A. J. Reichl, "Historic preservation and progrowth politics in U.S. cities," Urban Affairs Review, vol. 32, no. 4, pp. 513-535, 1997.

[9] P. N. Rigos and D. Paulson, "Urban development, policy failure, and regime change in a manager-council city the case of St. Petersburg, Florida," Urban Affairs Review, vol. 32, no. 2, pp. 244-263, 1996. 
[10] K. Warner and H. Molotch, "Power to build. How development persists despite local controls," Urban Affairs Review, vol. 30, no. 3, pp. 378-406, 1995.

[11] L. W. Bachelor, "Regime maintenance, solution sets, and urban economic development," Urban Affairs Quarterly, vol. 29, no. 4, pp. 596-616, 1994.

[12] R. Kerstein, "Suburban growth politics in Hillsborough county: growth management and political regimes," Social Science Quarterly, vol. 74, no. 3, pp. 614-630, 1993.

[13] J. A. Grant, "Making policy choices: local government and economic development," Urban Affairs Quarterly, vol. 26, no. 2, pp. 148-169, 1990.

[14] D. Fasenfest, "Community politics and urban redevelopment: Poletown, Detroit, and general motors," Urban Affairs Quarterly, vol. 22, no. 1, pp. 101-123, 1986.

[15] P. Dreier and B. Ehrlich, "Downtown development and urban reform: the politics of Boston's linkage policy," Urban Affairs Quarterly, vol. 26, no. 3, pp. 354-375, 1991.

[16] E. G. Goetz, "Type II policy and mandated benefits in economic development," Urban Affairs Quarterly, vol. 26, no. 2, pp. 170-190, 1990.

[17] J. A. Whitt and J. Lammers, "The art of growth: ties between development organizations and the performing arts," Urban Affairs Quarterly, vol. 26, no. 3, pp. 376-393, 1991.

[18] P. Clavel, J. Pitt, and J. Yin, "The community option in urban policy," Urban Affairs Review, vol. 32, no. 4, pp. 435-458, 1997.

[19] R. Florida, The Rise of the Creative Class, Basic Books, New York, NY, USA, 2002.

[20] E. Strom, "Culture, art, and downtown development," in American Politics in a Global Age, P. Kantor and D. Judd, Eds., Longman, New York, NY, USA, 2010.

[21] B. Knudsen, R. Florida, K. Stolarick, and G. Gates, "Density and creativity in U.S. Regions," Annals of the Association of American Geographers, vol. 98, no. 2, pp. 461-478, 2008.

[22] L. A. Reese and G. Sands, "Making the least of our differences? Trends in local economic development in Ontario and Michigan, 1990-2005," Canadian Public Administration, vol. 50, no. 1, pp. 79-99, 2007.

[23] L. A. Reese, "Do we really need another typology? Clusters of local economic development strategies," Economic Development Quarterly, vol. 20, no. 4, pp. 368-376, 2006.

[24] M. Lubell, R. C. Feiock, and E. E. R. de la Cruz, "Local institutions and the politics of urban growth," American Journal of Political Science, vol. 53, no. 3, pp. 649-665, 2009.

[25] C. Jarmon, J. Vanderleeuw, M. Pennington, and T. Sowers, "The role of economic development corporations in city economic development," Economic Development Quarterly. In press.

[26] A. Lewis, "Steps to creating an economic development corporation," Center for Community and Economic Development, 2003, http://www.uwex.edu/ces/CCED .

[27] B. C. McCabe, R. C. Feiock, J. C. Clingermayer, and C. Stream, "Turnover among city managers: the role of political and economic change," Public Administration Review, vol. 68, no. 2, pp. 380-386, 2008.

[28] B. Liu and J. M. Vanderleeuw, "Economic development priorities and central-city and suburb differences," American Politics Research, vol. 32, no. 6, pp. 698-721, 2004.

[29] S. J. McGovern, "Mayoral leadership and economic development policy: the case of Ed Rendell's Philadelphia," Policy and Politics, vol. 25, no. 2, pp. 153-172, 1997.

[30] C. Kevin and A. Wood, "Local government and local economic development in the United States," Regional Studies, vol. 28, no. 6, pp. 640-646, 1994.
[31] C. James and R. Feiock, "Constituencies, campaign support, and council member intervention in city Development Policy," Social Science Quarterly, vol. 74, no. 1, pp. 199-215, 1993.

[32] L. Wise, "The public service culture," in Public Administration: Conceptsand Cases, R. Stillman, Ed., Houghton Mifflin, New York, NY, USA, 2005.

[33] G. Frederickson and D. Hart, "The public service and the patriotism of benevolence," in Public Service: Callings, Commitments, and Contributions, M. Holzer, Ed., Westview Press, Boulder, Colo, USA, 2000.

[34] S. Neuse, "The public service ethic and the professions in state government," in Public Service: Callings, Commitments, and Contributions, M. Holzer, Ed., Westview Press, Boulder, Colo, USA, 2000.

[35] J. M. Vanderleeuw, M. E. Sandovici, and C. A. Jarmon, "Women city leaders and Postmaterialist values: gender differences in economic development priorities," Journal of Women, Politics and Policy, vol. 32, no. 3, pp. 211-236, 2011.

[36] J. Camobreco and M. Barnello, "Postmaterialism and postindustrialism: cultural influences on female representation in state legislatures," State Politics and Policy Quarterly, vol. 3, no. 2, pp. 117-138, 2003.

[37] D. W. Davis, "Individual level examination of postmaterialism in the U.S.: political tolerance, racial attitudes, environmentalism, and participatory norms," Political Research Quarterly, vol. 53, no. 3, pp. 455-475, 2000.

[38] R. Inglehart and P. R. Abramson, "Measuring postmaterialism," American Political Science Review, vol. 93, no. 3, pp. 665677, 1999.

[39] K. Meier and J. Bohte, Politics and the Bureaucracy: Policy Making in the Fourth Branch of Government, Wadsworth/ Thompson Learning, Belmont, Australia, 2006.

[40] L. R. Keiser, V. M. Wilkins, K. J. Meier, and C. A. Holland, "Lipstick and logarithms: gender, institutional context, and representative bureaucracy," American Political Science Review, vol. 96, no. 3, pp. 553-564, 2002.

[41] M. Eisner, Antitrust and the Triumph of Economics, University of North Carolina Press, Chapel Hill, NC, USA, 1991.

[42] D. Hodges and H. Durant, "The professional state revisited: twixt Scylla and Charybdis?" Public Administration Review, vol. 49, no. 5, pp. 474-485, 1989.

[43] R. Fox and R. Schuhmann, "Gender and the role of the city manager," Social Science Quarterly, vol. 81, no. 2, pp. 604-621, 2000.

[44] J. Levy, Contemporary Urban Planning, Prentice Hall, Upper Saddle River, NJ, USA, 1997.

[45] P. G. Lewis, "Looking outward or turning inward? Motivatiions for development decisions in California central cities and suburbs," Urban Affairs Review, vol. 36, no. 5, pp. 696-720, 2001.

[46] "News," Tech. Rep., Bureau Labour of Statistics, United States Department of Labor, Washington, DC, USA, 2005, http://www.bls.gov/news.release/archives/laus_03102005.pdf .

[47] Texas Ahead, "Texas economy in focus: comptroller's economic outlook," 2011, http://www.texasahead.org/economy/ outlook.html.

[48] "News release," Tech. Rep., Bureau of Labor Statistics, United States Department of Labor, Washington, DC, USA, 2011, http://www.bls.gov/news.release/pdf/empsit.pdf .

[49] J. Lewison, "Texas unemployment rate hits highest level since before Perry endorsed gore," Daily Kos, 2011, http:// www.dailykos.com/story/2011/08/19/10086-10/-texas-unemployment-rate-hits-highest-level-sinde-before-perry-endore-sedgore 
[50] p. Teske and M. Schneider, "The Bureaucratic entrepreneur: the case of city managers," Public Administration Review, vol. 54, no. 4, pp. 331-340, 1994.

[51] J. Nalbandian, "A new professionalism in city managers," in Executive Leadership in the Public Service, R. Denhardt and W. Stewart, Eds., University of Alabama Press, Tuscaloosa, Ala, USA, 1992.

[52] R. Burby and P. May, "Making governments plan: State experiments in managing land use, Johns Hopkins University Press," Baltimore, 1997.

[53] J. H. Svara, "The shifting boundary between elected officials and city manager in large council-manager cities," Public Administration Review, vol. 59, no. 1, pp. 44-53, 1999.

[54] M. P. Blanco, "Preliminary assessment of statutory compliance of $4 \mathrm{~A}$ and $4 \mathrm{~B}$ economic development corporations in Texas with the development corporation act of 1979," Applied Research Projects Paper 300, Texas State University, San Marcos, Tex, USA, 2009, http://ecommons.txstate.edu/arp/300 . 


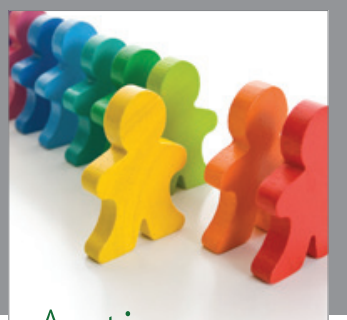

Autism

Research and Treatment
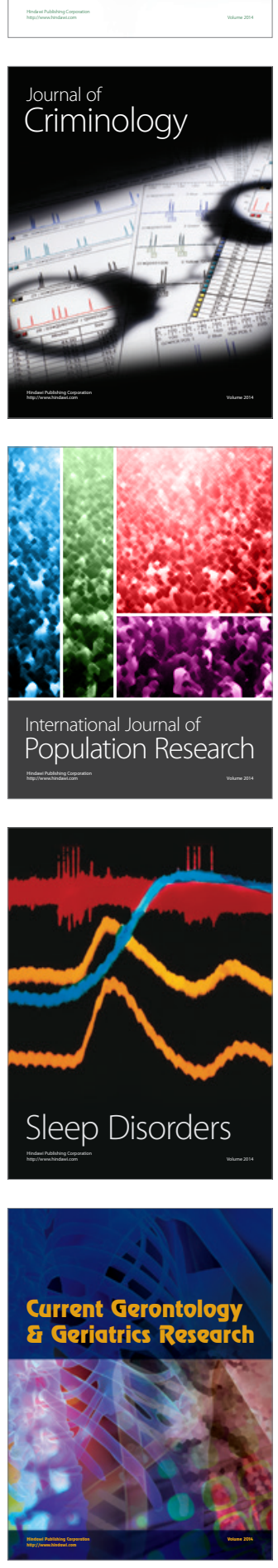
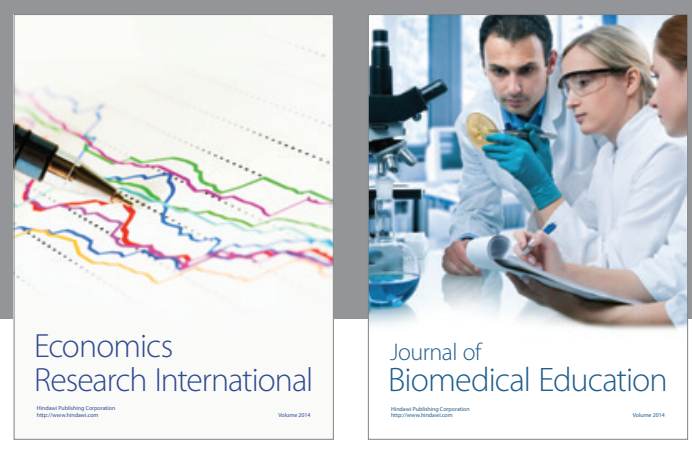

Journal of

Biomedical Education

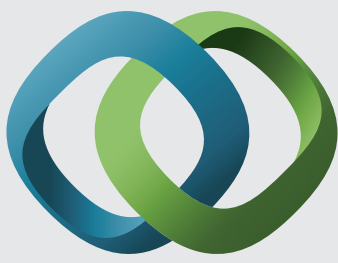

\section{Hindawi}

Submit your manuscripts at

http://www.hindawi.com
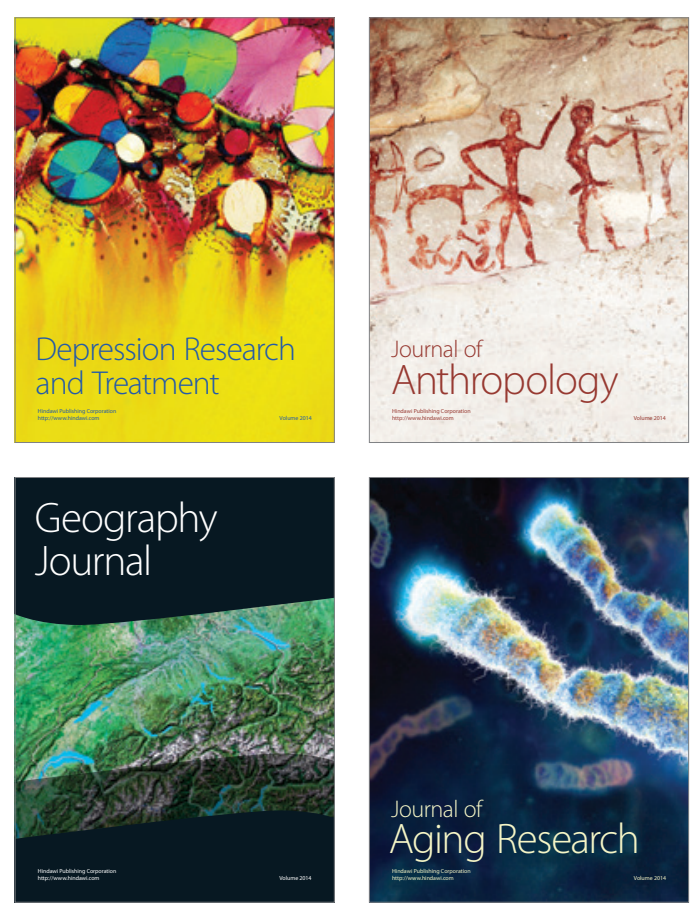

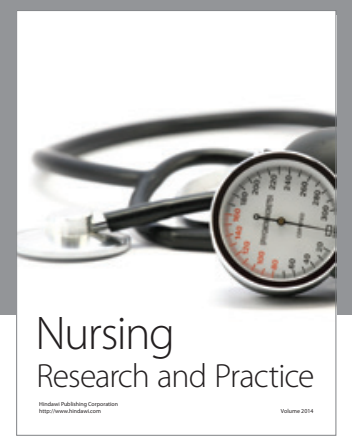

Nursing

Research and Practice

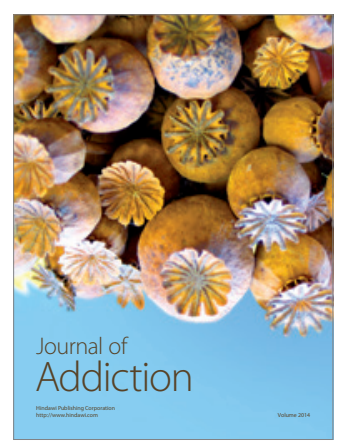

Child Development

Research

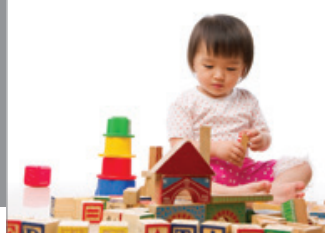

迥
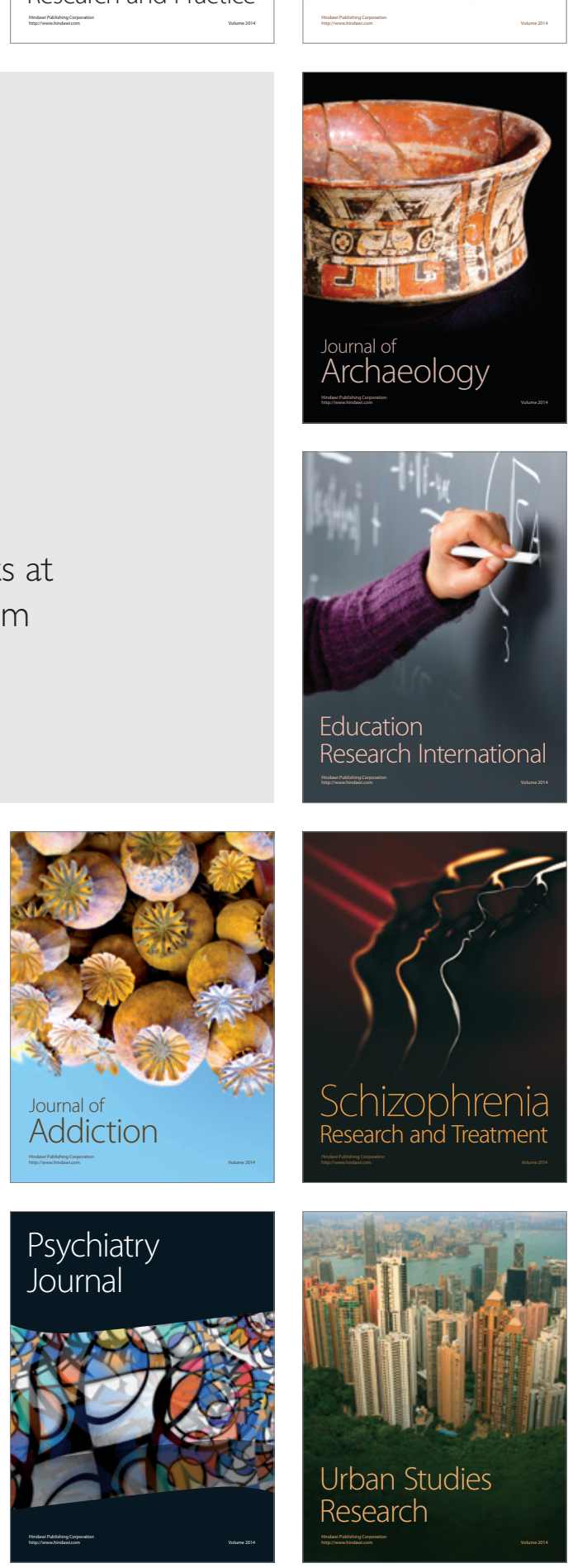